\title{
BREWER'S MEDIUM AS A METHOD OF INDUCING SICKLING IN SUSCEPTIBLE CELLS
}

\author{
BY \\ F. E. D. GRIFFITHS AND W. GRIMSHAW \\ From the Pathology Department, Marston Green Maternity Hospital, near Birmingham
}

(RECEIVED FOR PUBLICATION SEPTEMBER 18, 1954)

While investigating possible causes of anaemia, cholaemia, and uraemia in a woman of pure Negro stock, sickling of the erythrocytes was found in wet-blood smears. (Electrophoretic investigations of the patient's haemoglobin demonstrated that the patient was a heterozygote, showing the sickletrait pattern A-S.)

The original investigations were undertaken during a haemolytic crisis, and among the investigations a blood culture was made using glucose broth and Brewer's medium. The media remained sterile until discarded after 10 days. It was found that the glucose broth contained blood of normal appearance, apart from slight crenation of the red cells.

On removal of a sample of blood from the Brewer's medium it was seen that the red cells were sickled, and that no attempt was made by the cells to revert to normal contours. The Brewer's medium had been sealed by a cotton-wool plug inserted in the mouth of the tube, but no oil had been placed on the surface of the medium. The experiment was repeated and several smears made and stained by Leishman's method. The cells were typical of sickle-cell disease, and resembled those found by other methods, e.g., vaseline-sealed wet smears, blood-under-oil in Wintrobe oxalate mixture, in heparinized tubes, and in sealed wet smears containing Bact. coli. With all these methods formalin has to be used to fix the cells in the sickled state. This gives adequate fixation, but the subsequent staining is not always satisfactory.

The use of Brewer's medium not only obviates the necessity of using formalin to fix the red cells in the sickled state, but provides material from which smears can be stained in the ordinary routine manner.

Brewer's medium is nutrient broth containing $0.1 \%$ of sodium thioglycollate (thiolacetate) and $0.05 \%$ of agar. The induction of sickling and the subsequent fixation of the sickled cells would appear to be due to the thioglycollate present.

We are grateful to Dr. Hermann Lehmann, of the Department of Chemical Pathology, Saint Bartholomew's Hospital, London, for his report on the electrophoretic pattern of the patient's haemoglobin. 